\title{
An examination of the interaction between climate, soil and leaf area index in a Quercus ilex ecosystem
}

\author{
Corine Hoff* and Serge Rambal \\ DREAM, Centre d'Écologie Fonctionnelle et Évolutive (FRE 2633), CNRS, 34293 Montpellier, Cedex 5, France
}

(Received 2 Avril 2002; accepted 19 August 2002)

\begin{abstract}
In Mediterranean-type ecosystems, water availability is one of the most significant variables that regulates whole plant leaf area. An equilibrium should exist between climate, soil and leaf area in such water-limited conditions. The aim of this study was to identify the relations between leaf area index (LAI), environment (climate, soil) and fluxes (water, carbon) in Mediterranean evergreen oak (Quercus ilex L.) ecosystems. To achieve this objective, 50-years simulations were performed using the FOREST-BGC model by varying LAI for a reference site and for different climates and soil water holding capacities (SWC). Transpiration, drought stress, net photosynthesis and canopy water use efficiency (WUE) were examined on a yearly basis for the last ten years of the simulation. Similar to other findings, our results show that LAI depends on site water availability, including both climate (precipitation, potential evapotranspiration) and soil factors (e.g. water storage capacity). Low SWC limit the development of the ecosystem. On high SWC soils, development is mainly limited by the climate. When LAI increases under constant SWC and climate conditions, the decrease in annual transpiration per unit of LAI is accompanied by an increase in drought stress. Equilibrium LAI maximizes carbon assimilation. For the reference site, the equilibrium LAI is close to the observed value, 3.25 . The corresponding transpiration, assimilation and WUE are $375 \mathrm{~mm}, 1251 \mathrm{~g} \mathrm{C} \mathrm{m}^{-2}$ and $3.1 \mathrm{mmol} \mathrm{CO}_{2} \mathrm{~mol}^{-1} \mathrm{H}_{2} \mathrm{O}$, respectively. For the different sites, there is an hyperbolic decline of WUE with increasing SWC. This implies that production efficiency per unit leaf area is higher in most water-limited environments. Our study shows that a model such as FOREST-BGC allows inter-relations between water balance, carbon balance and drought stress to be taken into account to better understand ecosystem LAI.
\end{abstract}

leaf area index / hydrological equilibrium / water availability / climate / soil factor / Mediterranean-type ecosystem / Quercus ilex L. / evergreen oak

Résumé - Interactions entre climat, sol et surface foliaire dans un écosystème à Quercus ilex. Dans les écosystèmes méditerranéens, la disponibilité en eau est une des variables les plus significatives qui régulent la surface foliaire. Un équilibre doit exister entre le climat, le sol et la surface foliaire dans ces conditions de limitation en eau. L'objectif de cette étude est d'identifier les relations entre l'indice foliaire (LAI), l'environnement (climat, sol) et les flux (eau, carbone) pour les écosystèmes à chêne sempervirent méditerranéen Quercus ilex L. Pour cela, des simulations de 50 ans ont été effectuées avec le modèle FOREST-BGC en faisant varier le LAI pour un site de référence et pour différents climats et capacités en eau du sol (SWC). La transpiration, la contrainte hydrique, la photosynthèse nette et l'efficacité d'utilisation de l'eau de la canopée (WUE) ont été examinées au niveau annuel pour les dix dernières années de la simulation. Le LAI dépend de la disponibilité en eau du site qui inclue des facteurs climatiques (précipitation, évapotranspiration potentielle) et du sol (capacité du sol à stocker l'eau). Des faibles SWC limitent le développement de l'écosystème. À fort SWC, ce développement est principalement contrôlé par le climat. Quand LAI augmente sous climat et SWC constants, la diminution de la transpiration unitaire est accompagnée d'une augmentation de la contrainte hydrique. Le LAI d'équilibre maximise l'assimilation du carbone. Pour le site de référence, le LAI d'équilibre est proche de la valeur observée, 3,25. Les transpiration, assimilation et WUE correspondantes sont de $375 \mathrm{~mm}, 1251 \mathrm{~g} \mathrm{C} \mathrm{m}^{-2}$ et $3,1 \mathrm{mmol} \mathrm{CO}_{2} \mathrm{~mol}^{-1} \mathrm{H}_{2} \mathrm{O}$, respectivement. Aux différents sites, WUE décroît de manière hyperbolique avec l'augmentation de SWC. Ceci implique que l'efficacité de production par unité d'indice foliaire est plus importante dans les environnements les plus limités en eau. Notre étude montre qu'un modèle comme FOREST-BGC permet de prendre en compte les interrelations entre les bilans en eau et en carbone et la contrainte hydrique pour mieux comprendre la signification du LAI d'un écosystème.

indice foliaire / équilibre hydrologique / disponibilité en eau / climat / propriétés du sol / écosystème méditerranéen / Quercus ilex L. / chêne sempervirent

\section{INTRODUCTION}

Leaf area is a critical factor controlling water and carbon fluxes by plants. Leaf area is expressed as canopy density, percent cover, but more often as leaf area index (LAI), defined by the leaf area per unit of ground area.

In water-limited environments, such as the Mediterranean region, water availability strongly controls leaf initiation, leaf

* Corresponence and reprints

Tel.: 334676132 71; fax: 334674121 38; e-mail: hoff@cefe.cnrs-mop.fr 
fall and leaf quantity $[33,43]$. Important then are the timing of rainfall and drought events, the quantity of rainfall, the storage capacity of the soil and quantity and type of vegetation growing on a site. Part of the rainfall amount is stored in the soil and is available for further transpiration by plants. As a consequence, an equilibrium should exist between climate, soil retention properties, vegetation type and its leaf area. In addition, rainfall is unevenly distributed throughout the year resulting in marked seasonality in water availability. Thus, plants have to cope with varying and unpredictable levels of drought stress.

The short-term control of drought stress has often been studied through ecophysiological mechanisms, e.g. stomatal closure, whereas long-term controls, e.g. leaf area, have been less often examined. As Passioura [48] noted: "It is the control of leaf area index and morphology which is often the most powerful means a mesophytic plant has for influencing its fate when subject to long term water stress in the field". Similarly, Brown [4] observed that "where water may be limiting, trees appear to adjust to potential water stress through leaf morphology adaptations and minimum canopy development". Poole and Miller [50] have further summarized the adjustment of leaf area for some Mediterranean shrub species in the Californian chaparral: "the main response of the shrubs to different precipitation regimes in the chaparral range is to change leaf-area index, not physiological parameters".

Eagleson [15] is the first author to have derived a onedimensional, statistical-dynamic model for the equilibrium between the hydrological and the biological components of an ecosystem. He assumed that in water-limited environments, ecosystems develop a stable canopy density, which maximized biomass and minimized drought stress. In the case of an individual leaf, the minimization of drought stress can be made through the degree to which the stomata are open. Stomata closure limits transpiration, but also limits carbon assimilation. Thus, there is a trade-off between water loss and carbon assimilation at the scale of the leaf $[9,10]$. At the ecosystem scale, there should also a tradeoff or balance between LAI's role on water loss and its role in carbon gain [22].

Progress in ecosystem research has allowed the development of models linking transpiration and photosynthesis to environmental conditions. In these models, LAI plays an important role. It can constitute a variable for either prognosis or diagnosis. FOREST-BGC [61, 62] simulates the flows of water, carbon and biomass through forest ecosystems and provides a calculation of predawn leaf water potential, an index for plant drought stress on a daily basis. This model appears well suited to explore the concept of hydrological equilibrium in a wide range of climates and soils supporting woody vegetation. Moreover this model has been previously evaluated against data for the evergreen oak (Quercus ilex L.) ecosystem [27], a dominant forest ecosystem in the western Mediterranean Basin $[57,73]$. In our study, FOREST-BGC was used to (1) examine relations between the LAI and both climatic and soil factors; (2) understand how the water and carbon balances behave as a function of water availability and LAI; and (3) define how the balance between LAI and environmental conditions can be expressed.

\section{MATERIALS AND METHODS}

\subsection{The ecosystem simulation model}

FOREST-BGC $[61,62]$ is a process-based model of water, carbon and nitrogen cycles within an homogeneous forest ecosystem. FOREST-BGC has a dual time step. Water and most of the carbon variables are calculated on a daily basis, whereas nitrogen and carbon pools are updated each year. The model requires daily climate input data: minimum and maximum air temperature, relative humidity, incident short-wave radiation and precipitation. It also requires some key parameters describing vegetation and soil properties such as leaf area index and soil water holding capacity (SWC).

For the water cycle, daily precipitation is considered to be either rain or snow depending on air temperature. A canopy interception fraction based on LAI is then directly evaporated. Soil evaporation is not taken into account. The remaining input water enters the soil compartment until SWC is filled. Water in excess is lost by deep drainage. Predawn leaf water potential is calculated by assuming that there is an equilibrium between the plant and soil potentials after night recovery even if some disequilibrium may occur in natural conditions [14]. Transpiration is calculated with the PenmanMonteith "big-leaf" approach. The canopy resistance is controlled by (1) solar radiation computed assuming an extinction of solar radiation through the canopy and using Beer's extinction function of LAI; (2) nighttime minimum air temperature; (3) predawn leaf water potential; and (4) vapor pressure deficit.

For the carbon cycle, canopy gross photosynthesis is calculated by multiplying the $\mathrm{CO}_{2}$ gradient between ambient air and the chloroplasts by a diffusion resistance sum of canopy and mesophyll resistances [37]. Mesophyll resistance depends on leaf nitrogen content, solar radiation and daylight mean air temperature. Maintenance respirations for leaf, stem and fine root compartments are $\mathrm{Q}_{10}$ functions of air temperature.

At the end of each year, the net assimilated carbon is allocated to the stand compartments. This allocation is made using the following priorities: (1) maintenance respiration; (2) growth respiration; (3) leaf growth; (4) fine root growth; and (5) stem growth. The rule for allocating to the leaf compartment has not been changed from the previous works of Running and Gower [62]. Wood increment in FOREST-BGC is an end-member that includes all the uncertainties of the model. Allocation to this compartment was done after allocation to the leaf and fine root compartments. Carbon is lost by turnover of leaves and fine roots that enter the litter compartment. The decomposition rate of litter depend on soil water content and air temperature.

\subsection{Changes to the early version of FOREST-BGC}

There were two major changes to the default version of the FOREST-BGC model [61, 62] to adapt it for Quercus ilex ecosystems [27].

First, the soil water potential was calculated from the equation of Campbell [5] to reproduce the highly negative leaf water potentials measured in Mediterranean forest ecosystems. Secondly, we have assumed that $100 \%$ of the wood was respiring according to respiration measurements done on small diameter trunks of a $Q$. ilex coppice (unpublished data),

\subsection{Study sites}

The Puéchabon (PUEC) site is located $35 \mathrm{~km} \mathrm{NW}$ of Montpellier, southern France ( $3^{\circ} 35^{\prime} 45^{\prime \prime}$ E, $43^{\circ} 44^{\prime} 29^{\prime \prime} N$, elevation $\left.270 \mathrm{~m}\right)$. The soil is a hard Jurassic limestone with a clay soil that in places fills 
Table I. Values of FOREST-BGC parameters for Quercus ilex species [27]. Default values are used for the other parameters. Complete definition of FOREST-BGC parameters can be found in the original papers of Running and Coughlan [61] and Running and Gower [62].

\begin{tabular}{|c|c|c|c|}
\hline Parameter & Value & Unit & Reference \\
\hline Leaf mass per area & 190 & $\mathrm{~g} \mathrm{~m}^{-2}$ & {$[56]$} \\
\hline Canopy light extinction coefficient & 0.72 & dimensionless & {$[56]$} \\
\hline Soil water holding capacity & 170 & $\mathrm{~mm}$ & {$[16,52]$} \\
\hline Latitude & 43.7 & degree & \\
\hline 1 - surface albedo & 0.88 & dimensionless & [39] \\
\hline $\begin{array}{l}\text { Maximum canopy average leaf } \\
\text { conductance }\end{array}$ & 0.025 & $\mathrm{~m} \mathrm{~s}^{-1}$ & {$[32,67,72,74]$} \\
\hline $\begin{array}{l}\text { Leaf water potential at stomatal } \\
\text { closure }\end{array}$ & -3.5 & $\mathrm{MPa}$ & {$[11,12,55]$} \\
\hline Maximum mesophyll conductance & 0.0008 & $\mathrm{~m} \mathrm{~s}^{-1}$ & {$[59]$} \\
\hline $\begin{array}{l}\text { Minimum temperature } \\
\text { of photosynthesis }\end{array}$ & 0 & ${ }^{\circ} \mathrm{C}$ & \\
\hline $\begin{array}{l}\text { Maximum temperature } \\
\text { of photosynthesis }\end{array}$ & 40 & ${ }^{\circ} \mathrm{C}$ & \\
\hline Leaf respiration coefficient & 0.00012 & $\mathrm{~g} \mathrm{C} \mathrm{g} \mathrm{C}^{-1}$ day $^{-1}$ & $\begin{array}{l}{[41,47],} \\
\text { (Moreno, } \\
\text { unpublished } \\
\text { data) }\end{array}$ \\
\hline Wood respiration coefficient & 0.000012 & $\mathrm{~g} \mathrm{C} \mathrm{g} \mathrm{C}^{-1}$ day $^{-1}$ & {$[78]$} \\
\hline Fine root respiration coefficient & 0.00033 & $\mathrm{~g} \mathrm{C} \mathrm{g} \mathrm{C}^{-1}$ day $^{-1}$ & {$[63]$} \\
\hline $\mathrm{Q}_{10}$ & 2.3 & Dimensionless & {$[38,47]$} \\
\hline $\begin{array}{l}\text { Maximum canopy average leaf } \\
\text { nitrogen concentration }\end{array}$ & 0.0396 & $\mathrm{~g} \mathrm{~N} \mathrm{~g}^{-1} \mathrm{C}$ & {$[56]$} \\
\hline $\begin{array}{l}\text { Minimum canopy average leaf } \\
\text { nitrogen concentration }\end{array}$ & 0.0242 & $\mathrm{~g} \mathrm{~N} \mathrm{~g}^{-1} \mathrm{C}$ & {$[56]$} \\
\hline $\begin{array}{l}\text { Leaf nitrogen retranslocation } \\
\text { fraction }\end{array}$ & 0.27 & dimensionless & {$[19,38]$} \\
\hline Leaf turnover rate & 1.5 & year & $\begin{array}{l}{[19,20,29,36,} \\
\text { 39], (Rapp, } \\
\text { pers. com.) }\end{array}$ \\
\hline Leaf lignin fraction & 15.8 & $\%$ & {$[12]$} \\
\hline Date of spring leaf growth & 0 & day of year & evergreen \\
\hline Date of fall leaf drop & 365 & day of year & evergreen \\
\hline Atmospheric deposition of nitrogen & 1.5 & $\mathrm{~g} \mathrm{~m}^{-2}$ year $^{-1}$ & {$[38]$} \\
\hline Biological fixation of nitrogen & 1.3 & $\mathrm{~g} \mathrm{~m}^{-2}$ year $^{-1}$ & {$[38]$} \\
\hline Stem turnover coefficient & 0.01 & fraction year $^{-1}$ & \\
\hline Fine root turnover coefficient & 0.9 & fraction year $^{-1}$ & \\
\hline Leaf growth respiration coefficient & 0.22 & $\mathrm{~kg} \mathrm{~kg}^{-1} \mathrm{C}$ & {$[12]$} \\
\hline $\begin{array}{l}\text { Stem growth respiration } \\
\text { coefficient }\end{array}$ & 0.22 & $\mathrm{~kg} \mathrm{~kg}^{-1} \mathrm{C}$ & {$[76]$} \\
\hline $\begin{array}{l}\text { Fine root growth respiration } \\
\text { coefficient }\end{array}$ & 0.22 & $\mathrm{~kg} \mathrm{~kg}^{-1} \mathrm{C}$ & \\
\hline $\begin{array}{l}\text { Temperature optimum } \\
\text { of decomposition }\end{array}$ & 20 & ${ }^{\circ} \mathrm{C}$ & {$[28]$} \\
\hline Soil/litter C decomposition fraction & 0.0005 & dimensionless & $\begin{array}{l}\text { (Joffre, } \\
\text { unpublished } \\
\text { data) }\end{array}$ \\
\hline Decomposition rate scalar & 0.85 & dimensionless & $\begin{array}{l}\text { [8], (Joffre, } \\
\text { unpublished } \\
\text { data) }\end{array}$ \\
\hline
\end{tabular}

deep karstic fissures. The measured SWC is $170 \mathrm{~mm}$. The climate is Mediterranean with most abundant rainfall in spring and autumn. The vegetation consists of a uniform canopy of evergreen oak (Quercus ilex L.) on which many measurements such as biomass [20], predawn leaf water potential [52], litter fall [29], annual wood growth [17, 18] have been done since 1983. The FOREST-BGC model was then evaluated against these data [27] once the parameters for $Q$. ilex ecosystem were established from literature and measurements (see table I).

In the Mediterranean region two other sites with more or less rainfall but the same rainfall pattern as the PUEC site were chosen in order to represent a precipitation range within this ecosystems. The location and characteristics of each site are given in table II. The ratio of $\mathrm{P}$ to annual potential evapotranspiration (PET) was calculated using Penman-Monteith estimates [42]. Gruissan (GRU) is the driest site whereas Saint-Martin-de-Londres (SML) is the wettest. Daily data for precipitation, temperature and radiation were obtained from the records made by the nearest automatic meteorological stations for the period 1984-1993. Radiation records were available for the whole period only for PUEC and for the years 1990, 1991 and 1992 for GRU. Linear regression between the two stations $\left(r^{2}=0.87\right.$, $P<0.001)$ was used to extrapolate the GRU radiation series. Since the distance between PUEC and SML is only $15 \mathrm{~km}$, the same radiation values were used for both sites.

\subsection{Simulations and selected variables}

Simulations corresponding to a period of 50 years were run using the climatic data for the period 1984-1993 five times in succession. The initial biomass values were $25 \mathrm{~g} \mathrm{C} \mathrm{m}^{-2}$ for leaves, $655 \mathrm{~g} \mathrm{C} \mathrm{m}^{-2}$ for aerial wood and coarse roots and $44 \mathrm{~g} \mathrm{C} \mathrm{m}^{-2}$ for fine roots. The results focused on the last ten years of simulation for which the simulated values were stable and the ecosystem was mature. We were not concerned with inter-annual variations.

Four variables were selected from the simulation results for presentation:

- the number of days per year when predawn leaf water potential was below the critical value for stomatal closure $(-3.5 \mathrm{MPa})$ : a measure of the seasonal degree of drought stress;

- the terms of the annual water budget equation and, particularly, transpiration;

- the net annual photosynthesis defined as gross photosynthesis minus maintenance respiration of the leaf compartment;

- the annual canopy water use efficiency (WUE). It represents the ratio of net primary production (NPP) to annual transpiration.

These four variables were analyzed at the PUEC site for the observed $1984-1993$ period and SWC $=170 \mathrm{~mm}$ by varying LAI from 2 to 6, a range commonly found in $Q$. ilex canopies [12]. We expect that LAI between 2.5 and 3.5, common to mature stands in the PUEC area [29], would show the optimum transpiration/photosynthesis balance for the local meteorological and soil conditions. A similar optimum was then searched for different climatic conditions (PUEC, SML and GRU sites) and SWCs. The range of SWC depends on both rooting depth and soil properties. Quercus ilex like other Mediterranean oak species has been shown to be a deep-rooted species $[30,51]$. On karstic soils, characterized by stone and rock contents that can reach $90 \%$ or more, root uptake of soil water has been observed to occur at $5 \mathrm{~m}$ (Rambal, unpublished data). For example, a water content at field capacity of $0.3 \mathrm{~cm}^{3} \mathrm{~cm}^{-3}$ for the fine fraction of the soil and a stone content of $90 \%$ yield SWC of $(1-0.9) \times 0.30 \times$ $5000=150 \mathrm{~mm}$. For the lower limit, $100 \mathrm{~mm}$ has been retained, that is $93 \%$ of coarse elements. For the upper limit, on soil with low amounts of coarse elements, the rooting depth is limited to $2.5 \mathrm{~m}$ ([6] and personal observations). So, the SWC may be bound approximately by $0.3 \times 2500=750 \mathrm{~mm}$, a value validated by Teixeira [71]. 
Table II. Localization and climatology over the period 1984-1993 for the three sites: Gruissan GRU, Puéchabon PUEC and Saint-Martin-deLondres SML. $\mathrm{T}_{\mathrm{n}}$ and $\mathrm{T}_{\mathrm{x}}$ are mean annual minimum temperature and mean annual maximum temperature. The ratio between annual precipitation $\mathrm{P}$ and annual potential evapotranspiration PET is also presented.

\begin{tabular}{lcccccrcrc}
\hline \multicolumn{1}{c}{ Site } & Longitude & Latitude & $\begin{array}{c}\text { Altitude } \\
(\mathrm{m})\end{array}$ & $\begin{array}{c}\text { Precipitation } \\
\left(\mathrm{mm} \text { year }{ }^{-1}\right)\end{array}$ & $\mathrm{P} / \mathrm{PET}$ & $\begin{array}{c}\mathrm{T}_{\mathrm{n}} \\
\left({ }^{\circ} \mathrm{C}\right)\end{array}$ & $\begin{array}{c}\mathrm{T}_{\mathrm{x}} \\
\left({ }^{\circ} \mathrm{C}\right)\end{array}$ & $\begin{array}{c}\text { Incident shortwave radiation } \\
\left(\mathrm{kJ} \mathrm{cm}^{-2} \mathrm{year}^{-1}\right)\end{array}$ \\
\hline GRU & $3.13^{\circ} \mathrm{W}$ & $43.13^{\circ} \mathrm{N}$ & 1 & 630.7 & 0.6 & 10.9 & 19.0 & 4810 \\
PUEC & $3.59^{\circ} \mathrm{W}$ & $43.74^{\circ} \mathrm{N}$ & 250 & 782.4 & 0.73 & 8.7 & 17.8 & 4862 \\
SML & $3.73^{\circ} \mathrm{W}$ & $43.79^{\circ} \mathrm{N}$ & 200 & 1003.4 & 0.91 & 7.3 & 18.8 & 4862 \\
\hline
\end{tabular}
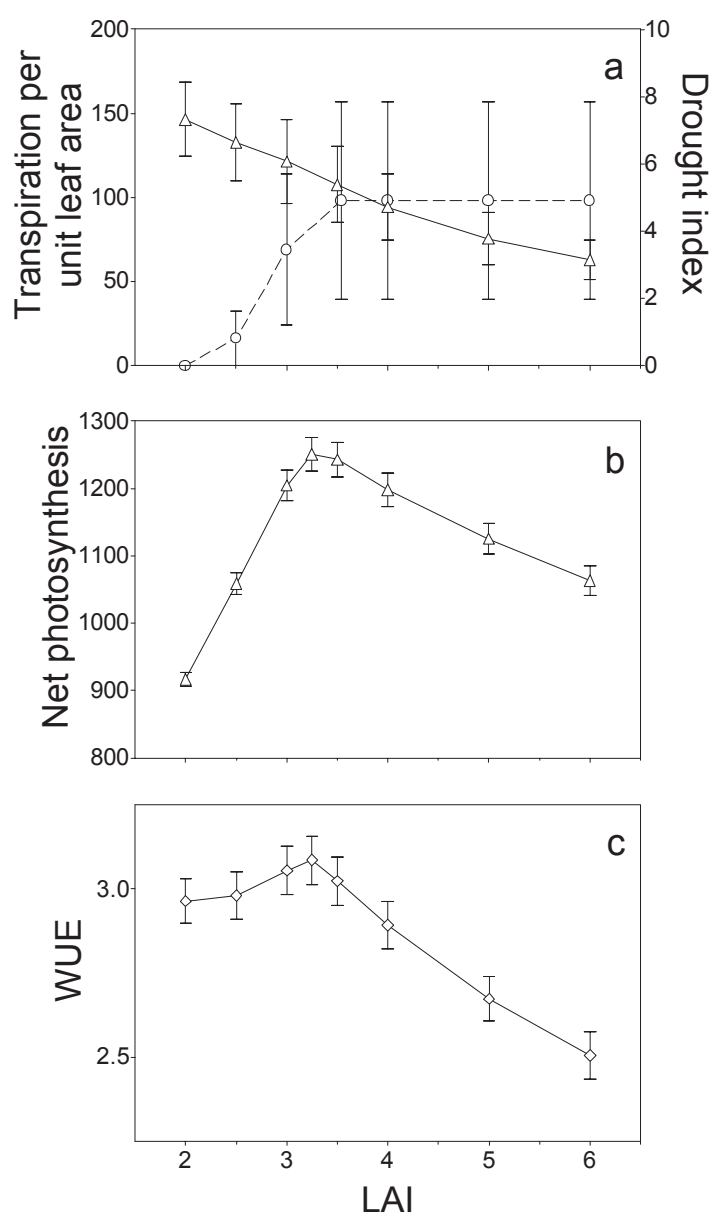

Figure 1. Responses of: (a) the annual transpiration per unit leaf area $\triangle(\mathrm{mm})$ and the drought index or the number of days per year when the predawn leaf water potential is below the critical value for stomatal closure $(-3.5 \mathrm{MPa}) \mathrm{O}$; (b) the annual net photosynthesis in $\mathrm{g} \mathrm{C} \mathrm{m}^{-2}$; and (c) water use efficiency in mmol $\mathrm{CO}_{2} \mathrm{~mol}^{-1} \mathrm{H}_{2} \mathrm{O}$ (WUE) to different values of leaf area index (LAI). Vertical bars represent standard error of the mean. The climate conditions are those of the site PUEC.

\section{RESULTS}

\subsection{Optimization of WUE at the PUEC site}

\subsubsection{Water budget}

The mean annual transpiration per unit LAI for the PUEC site shows a linear decrease ranging from $146.5 \mathrm{~mm}_{\text {year }}{ }^{-1}$ for a LAI of 2 to $62.4 \mathrm{~mm}$ year $^{-1}$ for an LAI of 6 (figure 1 a). Variations in transpiration as a function of LAI are accompanied by modifications in the partitioning of the ecosystem water balance. When LAI equals $2,55 \%$ of precipitation is lost by drainage and $36 \%$ used by transpiration. When LAI is 3 or more, transpiration represents $45 \%$ and drainage $44 \%$. The drought stress index or the number of days per year when predawn leaf water potential is below the critical value for stomatal closure $(-3.5 \mathrm{MPa})$ increases with simulated LAI (figure 1a). Over the 1984-1993 period, these mean number of days were zero for an LAI of 2 and 5 for an LAI of 3.5.

\subsubsection{Carbon budget and water use efficiency}

There is a marked increase in net annual photosynthesis with an increase in LAI up to 3.25 , when its maximum value equals $1251 \mathrm{~g} \mathrm{C} \mathrm{m}^{-2}$ year $^{-1}$ (figure 1 b). For an LAI of 2, WUE equals $2.9 \mathrm{mmol} \mathrm{CO}_{2} \mathrm{~mol}^{-1} \mathrm{H}_{2} \mathrm{O}$ (figure 1c). WUE increases slightly up to an LAI of 3.25 , when it reaches its maximum value at $3.1 \mathrm{mmol} \mathrm{CO}_{2} \mathrm{~mol}^{-1} \mathrm{H}_{2} \mathrm{O}$.

\subsection{Optimal transpiration/photosynthesis balance conditions under varying climate and soil conditions}

The simulated values for LAI obtained for each site (PUEC, SML, GRU) and each SWC will be those that gave the highest values for net photosynthesis and annual WUE.

\subsection{1. $L A I$}

For example, under historical climatic patterns, a LAI of 3.25 was optimum for the PUECH site. Optimum values of LAI ranged from 1.9 to 5.5 for the three sites under different SWC values (figure $2 a$ ). They increased from GRU to SML and with an increase in SWC. For GRU, an SWC of $350 \mathrm{~mm}$ was required to obtain an ecosystem with an LAI of 3.5 whereas for SML, an SWC of only $200 \mathrm{~mm}$ was sufficient. For an SWC of between 100 and $350 \mathrm{~mm}, \mathrm{LAI}$ increased from 1.9 to 3.8 at GRU, 2 to 4.4 at PUEC and 2.3 to 5.1 at SML. When SWC was over $350 \mathrm{~mm}$, sensitivity of LAI to SWC was reduced for the three sites. LAI values were statistically different between all sites when SWC was higher than $200 \mathrm{~mm}$ (ANOVA, $P<0.01$ ).

\subsubsection{Transpiration}

Transpiration increased at all three sites as SWC increased (figure $2 b$ ). Transpiration also increased from GRU to SML. It varies between $231.7 \mathrm{~mm}$ year $^{-1}$ at GRU with an SWC of $100 \mathrm{~mm}$ and $762.6 \mathrm{~mm} \mathrm{year}^{-1}$ at SML with an SWC 

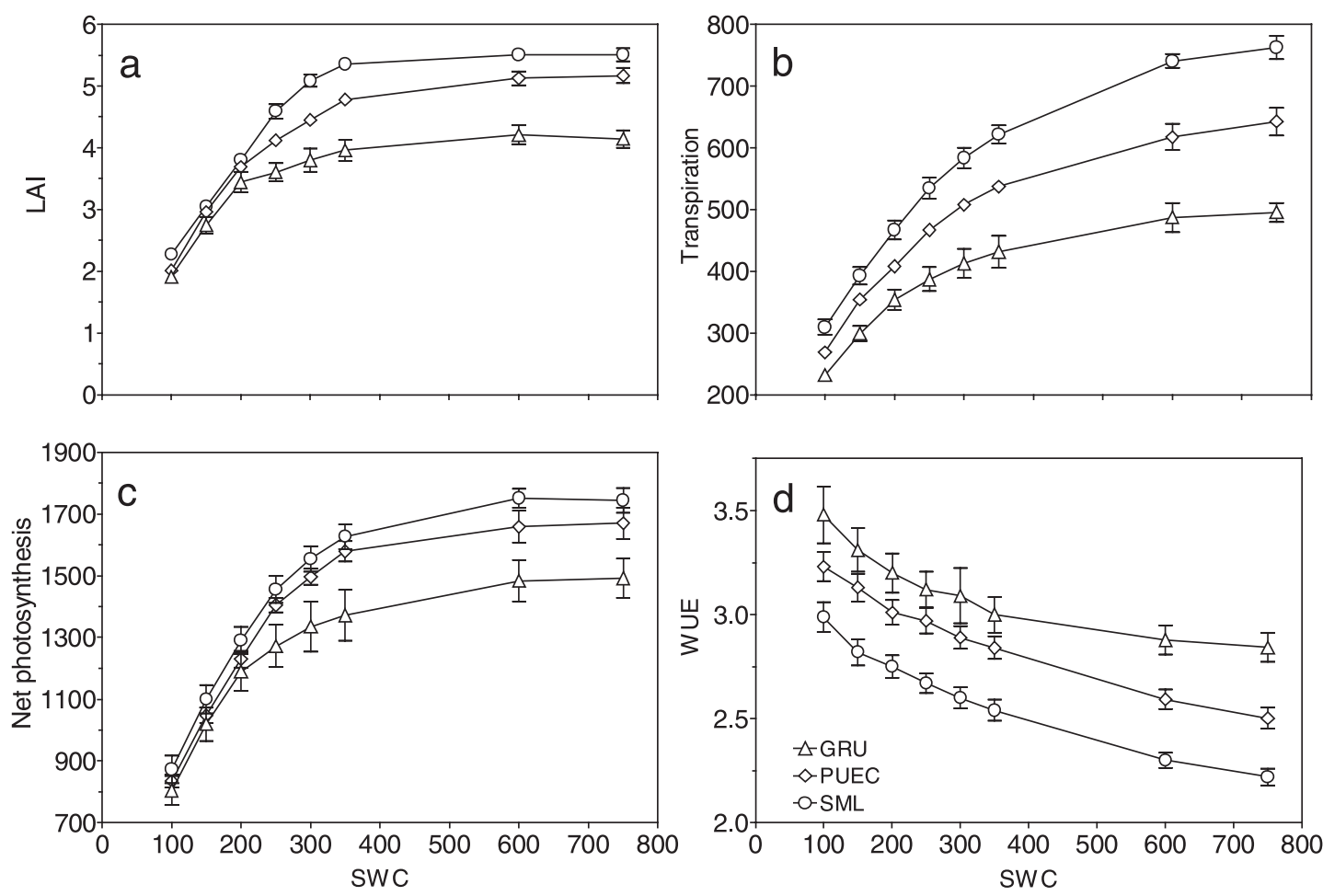

Figure 2. (a) Leaf area index (LAI); (b) annual transpiration in $\mathrm{mm}$; (c) annual net photosynthesis in $\mathrm{g} \mathrm{C}^{-2}$; and (d) water use efficiency in mmol CO mol-1 $^{-1} \mathrm{H}$ (WUE) obtained for the three sites GRU, PUEC, SML as a function of soil water holding capacity (SWC). Vertical bars represent standard error of the mean.

of $750 \mathrm{~mm}$. If SWC is higher than $200 \mathrm{~mm}$, transpiration values are statistically different between all sites (ANOVA, $P<0.01$ ).

\subsubsection{Net photosynthesis and water use efficiency}

Net annual photosynthesis behaves in a similar way to annual transpiration (figure 2c). Values range from $804 \mathrm{~g} \mathrm{C} \mathrm{m}^{-2}$ year-1 $^{-1}$ for GRU with an SWC of $100 \mathrm{~mm}$ and $1750 \mathrm{~g} \mathrm{C} \mathrm{m}^{-2}$ year $^{-1}$ for SML with an SWC of $750 \mathrm{~mm}$. As for transpiration, if SWC is higher than $200 \mathrm{~mm}$, net photosynthesis values are statistically different between all sites (ANOVA, $P<0.05$ ).

WUE decreases from GRU to SML and with increasing SWC (figure 2d). Values range from $2.2 \mathrm{mmol} \mathrm{CO}_{2} \mathrm{~mol}^{-1} \mathrm{H}_{2} \mathrm{O}$ for SML with an SWC of $750 \mathrm{~mm}$ to $3.5 \mathrm{mmol} \mathrm{CO}_{2} \mathrm{~mol}^{-1} \mathrm{H}_{2} \mathrm{O}$ for GRU with an SWC of $100 \mathrm{~mm}$. WUE values are statistically different between sites for all SWC values (ANOVA, $P<0.01$ ).

\section{DISCUSSION}

\subsection{Relating water availability and LAI}

What variable may be chosen for describing water availability? The most obvious climate variable affecting water availability is the quantity of rainfall $(\mathrm{P})$. It has been related to plant density [1, 31, 80] and canopy LAI [21, 77]. However other factors such as aspect, slope, position and site water balance can affect the relationship between $\mathrm{P}$ and plant properties. The ratio of rainfall amount to potential evapotranspiration P/PET has been successfully used in zoning vegetation in Mediterranean-type climate areas [34, $35]$ or at global scale [2, 3]. In our study, it is related with the equilibrium LAI among the three sites as in Nemani and Running [46] for coniferous forests. Site water balance appeared to better describe water availability [69]. Grier and Running [23] and Gholtz [21] found a significant correlation between LAI of coniferous forests and the site water balance during the growing season. Several approaches have been used to estimate large-scale patterns of sustainable leaf area. For mature "climax" evergreen canopies in Australia, Specht and Specht [68] related percent cover with an evaporative coefficient, ratio of actual to potential evapotranspiration. Woodward [81] simulated the soil water balance with a "big leaf" approach of canopy evapotranspiration and derived biome LAI. Neilson [45] extended this approach to predict seasonal distribution of LAI for grass and woody plants. They all neglected the large variations of soil properties that can be observed under a given vegetation type.

In all our sites, an increase in SWC resulted in an increased LAI. SWC lower than $200 \mathrm{~mm}$ sustained similar LAI irrespective of the climate. In such cases, SWC limits the development of the ecosystem because SWC is so small that any excess precipitation, both runoff and deep drainage, is unavailable to the plant. By contrast, vegetation that grows on soil with high SWC can use stored water during the periods when precipitations are fewer. Such an ecosystem has a higher transpiring capacity and can thus maintain a higher LAI. In this case, 
development of the ecosystem is mainly limited by the climate. Water availability must thus be defined not only as a function of the climate via precipitation and evapotranspiration requirements, but also as a function of the retention properties of the soil and of the rooting depth of the vegetation. The range of LAI obtained with varying water availability is in agreement with data of Damesin et al. [12]. Our maximum value is closed to the one observed at La Peyne site receiving similar rate and pattern of precipitations on a soil with very large SWC $[71,72]$.

LAIs were obtained for a mature ecosystem after a 50 years simulation. They thus reflect short- to mid-term acclimation of leaf area to water availability following Eagleson [15] and Hatton et al. [25]. For longer time scales, changes in species composition may be observed that are beyond the scope of this study $[23,44]$.

\subsection{LAI, drought stress and carbon assimilation}

LAI greatly affects site water balance. With increasing leaf area index, drainage decreases while transpiration and interception increases. The same changes in the partitioning of the water balance with LAI have also been obtained for coniferous forests [60] and for Mediterranean evergreen shrubland [53, 54]. When LAI increases under constant SWC and P conditions, the decrease in annual transpiration per unit of LAI is accompanied by an increase in drought stress. The intensity of drought stress is evidenced by the increase in the number of days per year when predawn leaf water potential is below the critical value for stomatal closure as shown in this study and in Running [60] and Rambal [53, 54]. It is therefore impossible to increase transpiration per unit of LAI without increasing drought stress. A trade-off exists between transpiration per unit of LAI and drought stress [53].

If water availability does control LAI, varying LAI while holding climate constant illustrates the optimum LAI for that climate in terms of transpiration/photosynthesis balance. This behavior is linked to competition for water and solar radiation predicted by Waring [77] for forest ecosystems and demonstrated by Running [60] in coniferous forests. Transpiration and net annual photosynthesis increase in a nonlinear manner as a function of water availability $[24,66]$.

The LAI of an evergreen oak ecosystem is thus linked to a maximization of carbon assimilation for minimum transpiration and drought stress. This corresponds to maximum WUE, which agrees with our results and Cohen's [7] hypothesis for plants growing in water-limited environments. The WUE of evergreen oak ecosystems varies in the same way as the intensity of the drought stress (see also [65]), i.e. inversely with the water availability. This finding agrees with measurements obtained by Damesin et al. [13] on the basis of the leaf $\delta^{13} \mathrm{C}$ signature in Quercus ilex trees growing in a rainfall gradient in southern France. This distinction in terms of leaf $\delta^{13} \mathrm{C}$ values implies a segregation of the long-term estimates of the ratio $\mathrm{C}_{\mathrm{i}} / \mathrm{C}_{\mathrm{a}}$ between intercellular $\mathrm{CO}_{2}$ concentration within leaves $\left(\mathrm{C}_{\mathrm{i}}\right)$ and atmospheric $\mathrm{CO}_{2}\left(\mathrm{C}_{\mathrm{a}}\right)$ and therefore of leaf performance and water use efficiency. Damesin et al. [13] significantly related both within- and between-site variabilities in leaf $\delta^{13} \mathrm{C}$ with the minimum seasonal leaf predawn potential. This response in $\delta^{13} \mathrm{C}$, and consequently in $\mathrm{C}_{\mathrm{i}} / \mathrm{C}_{\mathrm{a}}$, which tends to optimize the use of water resource can be extended to plant communities growing along a water availability gradient [70] and finally is in agreement with early results of Whittaker and Niering [79].

A sensitivity analysis at the PUEC site demonstrated that a LAI value exists for an evergreen oak ecosystem for which a balance is achieved concerning water balance loss, drought stress, carbon assimilation and water use efficiency. This balance was obtained at a leaf area index between 3 and 3.5. This interval is in agreement with the LAI of 3 observed at this site [29].

In summary, the LAI of evergreen oak ecosystems in the Mediterranean region corresponds to adjustment to drought stress and maximization of carbon assimilation and of WUE. LAI varies with site water availability, which leads us to look for a simple formulation linking LAI and environmental conditions.

\subsection{Predicting equilibrium between LAI and environmental conditions}

To understand ecosystem leaf area and fluxes (water, carbon) relations with environmental conditions several hypothesis have been made. We discuss here the main ones that could be applied for Mediterranean ecosystems.

(1) Transpiration depends on soil water availability and atmospheric evaporative demand, and has a strong influence on the physiological processes that determine growth. Poole and Miller [50], Miller [40] for chaparral and matorral and Nemani and Running [46] for coniferous forests, expressed the equilibrium hypothesis by using the ratio of annual transpiration to LAI. However this hypothesis is only valid if the extinction of solar radiation by the canopy is not too great, i.e. in the case of LAI $<3$. This is strongly challenged by our results which explore a wide range of water availability, and by estimates obtained for ecosystems in the Mediterranean area with different LAIs. In a Mediterranean shrubland, Rambal [53] found an annual transpiration per unit LAI of $193 \mathrm{~mm}$. The LAI of this ecosystem was 2.4. For the PUEC site, Hoff et al. [27] simulated a mean annual transpiration rate of $363 \mathrm{~mm}$ with a LAI of 2.9 This value is greater than that obtained for other Quercus ilex ecosystems. In the stands of l'Avic (NE Spain), Sala and Tenhunen [64] found annual totals of $453 \mathrm{~mm}$ and $464 \mathrm{~mm}$ for LAI values of 4.6 and 5.3, respectively. The annual quantities of water transpired per unit LAI were therefore $98.5 \mathrm{~mm}$ and $87.5 \mathrm{~mm}$. For the La Peyne site, Teixeira [71] and Teixeira et al. [72] measured an annual transpiration of $468 \mathrm{~mm}$ using the sap flow method. The mean LAI of the evergreen oaks in this ecosystem was 5.4 and the annual transpiration per unit LAI was therefore $86.7 \mathrm{~mm}$. The hypothesis "transpiration / LAI is constant" can not thus be used to describe the equilibrium of an evergreen oak ecosystem in all conditions of water availability. Our study has shown a non-linear relationship with an increase of transpiration with LAI until a maximum value at full water availability (climate and soil).

(2) According to Pierce et al. [49] transpiration alone does not provide a satisfactory index to account for plant drought stress, especially in the driest areas. These authors suggested indicating the intensity of drought stress by the predawn leaf water potential observed during the growth period $\bar{\psi}_{\mathrm{p}}$. They assumed that the development of LAI is inversely proportional 
to $\bar{\psi}_{\mathrm{p}}$. Having calculated LAI and $\bar{\psi}_{\mathrm{p}}$ for a reference site, their relation is written:

$$
\mathrm{LAI}_{\text {ref }} / \mathrm{LAI}_{\text {site }}=\left[\bar{\psi}_{\mathrm{p}}\right]_{\text {site }} /\left[\bar{\psi}_{\mathrm{p}}\right]_{\text {ref }} .
$$

A site that has less drought stress than the reference site could support a higher $\mathrm{LAI}_{\text {site }}$ than $\mathrm{LAI}_{\text {ref }}$ and vice versa. This approach appears potentially useful in the case of Mediterranean ecosystems where water availability is one of the major constraints [75]. Though FOREST-BGC provides the calculation of the predawn leaf water potential and uses it for processes limitation, tests of Pierce et al.'s [49] formula did not produce satisfactory results. For example, for the same SWC of $350 \mathrm{~mm}$, PUEC and SML sites had respectively an LAI of 4.8 and 5.3 but had the same drought stress. One explanation could be that the relation of Pierce et al. [49] is well-suited to arid or semi-arid environments and particularly to vegetation that faces drought stress during the growth period. This is not true in all sites where the growth takes place under the least limiting conditions.

(3) NPP of a large range of natural ecosystems has been correlated with water availability through actual evapotranspiration [58]. We have shown here that in a waterlimited environment the LAI of the vegetation depends on water availability. This can be summed up as a problem of balancing the benefits obtained by increasing LAI to capture radiation and the cost in terms of transpiration. Haxeltine et al. [26] limited the problem of optimization to the maximization of NPP. The question is whether natural vegetation should really be expected to maximize NPP. NPP can be used as an index for competition when there is no effect of succession or of age and when disturbances (cutting, fire, disease) are not taken into consideration, which was the case in our study. However this rule does not provide an equilibrium relationship with LAI.

We have shown that all these hypothesis are incomplete though describing the major constraints on ecosystem leaf area. The model FOREST-BGC brings together the major inter-relations with water budget equation members, drought stress and carbon flux and allows the treatment of non-linearities. We therefore recommend the use of such a model to describe the equilibrium between leaf area and environment. In the case of Mediterranean ecosystems the main constraint of environment is water availability related to climate and soil conditions. Our ecological approach of LAI significance could help to improve realistic evaluations of the issues of climate change and the global carbon cycle.

Acknowledgements: The original version of the FOREST-BGC model was provided by Dr. S.W. Running, School of Forestry, Missoula, MT, USA. We thank him for his help on the model. We also thank Dr. R. Nemani, School of Forestry, Missoula, MT, USA for interesting comments on the hydrological equilibrium concept. Valuable comments of Pr. T. Hinckley and those of an anonymous reviewer are gratefully acknowledged. This work is a contribution to the French program Carbofor of the GICC-MATE.

\section{REFERENCES}

[1] Beatley J.C., Effects of rainfall and temperature on the distribution and the behaviour of Larrea tridentata (creosote bush) in the Mojave desert of Nevada, Ecology 55 (1974) 245-261.
[2] Box E.O., Macroclimate and plant forms: an introduction to predictive modelling in phytogeography, Junk, The Hague, 1981.

[3] Box E.O., Factors determining distributions of tree species and plant functional types, Vegetatio 121 (1995) 101-116.

[4] Brown S., A comparison of the structure, primary productivity, and transpiration of cypress ecosystems in Florida, Ecol. Monographs 51 (1981) 403-427.

[5] Campbell G.S., A simple method for determining unsaturated conductivity from moisture retention data, Soil Science 117 (1974) 311-314.

[6] Canadell J., Rodà F., Root biomass of Quercus ilex in a montane Mediterranean forest, Can. J. Forest Res. 21 (1991) 1771-1778.

[7] Cohen D., The expected efficiency of water utilization in plants under different competition and selection regimes, Israel J. Botany 19 (1970) 50-54.

[8] Cortez J., Demard J.M., Bottner P., Jocteur Monrosier L., Decomposition of Mediterranean leaf litters: a microcosm experiment investigating relationships between decomposition rates and litter quality, Soil. Biol. Biochem. 28, 4/5 (1996) 445-452.

[9] Cowan I.R., Regulation of water use in relation to carbon gain in higher plants, in: Lange O.L., Nobel P.S., Osmond C.B., Ziegler H. (Eds.), Encyclopedia of plant physiology, 12B, Springer-Verlag, Berlin, 1982, pp. 589-613.

[10] Cowan I.R., Farquhar G.D., Stomatal function in relation to leaf metabolism and environment, in: Jennings D.H. (Ed.), Integration of activity in the higher plant, Cambridge University Press, Cambridge, MA, 1977, pp 471-505.

[11] Damesin C., Relations hydriques, photosynthèse et efficacité d'utilisation de l'eau chez deux chênes méditerranéens caduc et sempervirent co-ocurrents, Ph.D. Thesis, Paris XI Orsay, 1996.

[12] Damesin C., Rambal S., Joffre R., Cooccurrence of trees with different leaf habit: A functional approach on Mediterranean oaks, Acta Oecologica 19 (1998) 195-204.

[13] Damesin C., Rambal S., Joffre R., Seasonal and annual changes in leaf $\delta^{13} \mathrm{C}$ in two co-occuring Mediterranean oaks: relations to leaf growth and drought progression, Funct. Ecol. 12 (1998) 778-785.

[14] Donovan L.A., Linton M.J., Richards J.H., Predawn plant water potential does not necessary equilibrate with soil water potential under well-watered conditions, Oecologia 129 (2001) 328-335.

[15] Eagleson P.S., Ecological optimality in water limited natural soilvegetation systems. 1 . Theory and hypothesis, Water Resour. Res. 18 (1982) 325-340.

[16] Ed-Derfoufi F., Gestion et dynamique des nutrients dans des taillis de chêne vert âgés et très jeunes, Ph.D. Thesis, Montpellier II, 1986.

[17] Enjalbal M., Étude de l'accroissement radial du chêne vert (Quercus ilex L.), relation avec la variabilité climatique dans le basLanguedoc, DEA, Marseille, 1994.

[18] Enjalbal M., Grandjanny M., Maistre M., Perret P., Romane F., Shater Z., The holm oak (Quercus ilex L.), radial growth facing the rainfall unpredictability. An example in Southern France, Annali Istituto Sperimentale Selvicoltura 27 (1998) 31-37.

[19] Escudero A., Del Arco J.M., Garrido M.V., The efficiency of nitrogen retranslocation from leaf biomass in Quercus ilex ecosystems, Vegetatio 99/100 (1992) 225-237.

[20] Floret C., Galan M.J., Le Floch' E., Rapp M., Romane F., Organisation de la structure, de la biomasse et de la minéralomasse d'un taillis de chêne vert (Quercus ilex L.), Acta Oecol., Oecol. Plant. 10 (1989) 245-262.

[21] Gholz H.L., Environmental limits on aboveground net primary production, leaf area, and biomass in vegetation zones of the Pacific northwest, Ecology 63 (1982) 469-481.

[22] Gholz H.L., Ewel K.C., Teskey R.O., Water and forest productivity, For. Ecol. Manage. 30 (1990) 1-18.

[23] Grier C.C., Running S.W., Leaf area of mature coniferous forests: relation to site water balance, Ecology 58 (1977) 893-899.

[24] Hatton T.J., Wu H.I., Scaling theory to extrapolate individual tree water use to stand water use, Hydrol. Process. 9 (1995) 527-540. 
[25] Hatton T.J., Salvucci G.D., Wu H.I., Eagleson's optimality theory of an ecohydrological equilibrium: quo vadis? Funct. Ecol. 11 (1997) 665-674.

[26] Haxeltine A., Prentice I.C., Creswell I.D., A coupled carbon and water flux model to predict vegetation structure, J. Veg. Sci. 7 (1996) 651-666.

[27] Hoff C., Rambal S., Joffre R., Simulating carbon and water flows and growth in a Mediterranean evergreen Quercus ilex coppice using the FOREST-BGC model, For. Ecol. Manage. 164 (2002) 121-136.

[28] Ibrahima A., Approches expérimentale et spectroscopique de la décomposition de litières méditerranéennes, Ph.D. Thesis, Montpellier II, 1995.

[29] Joffre R., Rambal S., Romane F., Local variations of ecosystems functions in Mediterranean evergreen oak woodland, Ann. Sci. For. 53 (1996) 561-570.

[30] Joffre R., Rambal S., Damesin C., Functional attributes in Mediterranean-type ecosystems, in: Pugnaire F.I., Valladares F. (Eds.), Handbook of functional plant ecology, Marcel Dekker Inc., New York, 1999, pp. 347-380.

[31] Joffre R., Rambal S., Ratte J.-P., The dehesa system of southern Spain and Portugal as a natural ecosystem mimic, Agroforest. Syst. 45 (1999) 57-79.

[32] Kelliher F.M., Leuning R., Raupach M.R., Schultze E.D., Maximum conductances for evaporation from global vegetation types, Agr. Forest Meteorol. 73 (1995) 1-6.

[33] Kozlowski T.T., Water supply and leaf shedding, in: Kozlowski T.T. (Ed.), Water deficits and plant growth. IV. Soil water measurement, plant responses, and breeding for drought resistance, Academic Press, 1976, pp. 191-231.

[34] Le Houérou H.N., The arid bioclimates in the mediterranean isoclimatic zone, Ecologia Mediterranea 8 (1982) 103-114.

[35] Le Houérou H.N., Global change: vegetation, ecosystems, and land use in the southern mediterranean basin by the mid-twenty-first century, Israel J. Botany 39 (1990) 481-508.

[36] Leonardi S., Rapp M., Denes A., Étude de la dynamique du feuillage et de sa contribution à l'économie de nutrients dans deux taillis de Quercus ilex, Archivo Botanico Italiano 68 (1992) 103-133.

[37] Lohammar T., Larsson S., Linder S., Falk S.O., FAST-Simulation models of gaseous exchange in Scots pine, in: Persson T. (Ed.), Structure and Function of Northern Coniferous Forests - An ecosystem study, Ecol. Bull. 32 (1980) 505-523.

[38] Lossaint P., Rapp M., La forêt méditerranéenne de chênes verts, in Lamotte M., Bourlière F. (Eds.), Problèmes d'écologie. Écosystèmes terrestres, Masson, Paris, 1978, pp. 129-185.

[39] Méthy M., Interception du rayonnement solaire par différents types de végétation dans la région méditerranéenne, Ph.D. Thesis, Montpellier II, 1974.

[40] Miller P.C., Similarities and limitations of ressource utilization in Mediterranean Type Ecosystems, in: Miller P.C. (Ed.), Ressource use by chaparral and matorral. A comparison of vegetation function in two Mediterranean type ecosystems, Ecological Studies 39, Springer-Verlag, Berlin, 1981, pp. 369-407.

[41] Mitchell K.A., Bolstad P.V., Vose J.M., Interspecific and environmentally induced variation in foliar dark respiration among eighteen southeastern deciduous tree species, Tree Physiol. 19 (1999) 861-870.

[42] Monteith J.L., Principles of environmental physics, Arnold, London, 1973.

[43] Mooney H.A., Dunn E.L., Convergent evolution of mediterraneanclimate evergreen sclerophyll shrubs, Evolution 24 (1970) 292-303.

[44] Mouillot F., Rambal S., Joffre R., Simulating climate change impacts on fire frequency and vegetation dynamics in a Mediterranean-type ecosystem, Global Change Biology 8 (2002) 423-437.

[45] Neilson R.P., A model for predicting continental scale vegetation distribution and water balance, Ecol. Appl. 5 (1995) 362-386.
[46] Nemani R., Running S.W., Testing a theoretical climate-soil-leaf area hydrologic equilibrium of forests using satellite data and ecosystem simulation, Agr. Forest Meteorol. 44 (1989) 245-260.

[47] Oechel W.C., Lawrence W., Carbon allocation and utilization, in: Miller P.C. (Ed.), Ressource use by chaparral and matorral. A comparison of vegetation function in two Mediterranean Type Ecosystems, Ecological Studies 39, Springer-Verlag, Berlin, 1981, pp. 185-235.

[48] Passioura J.B., Physiology of grain yield in wheat growing on stored water, Aust. J. Plant Physiol. 3 (1976) 559-565.

[49] Pierce L.L., Walker J., Dowling T.I., McVicar T.R., Hatton T.J., Running S.W., Coughlan J.C., Ecohydrological changes in the Murray-Darling Basin. III. A simulation of regional hydrological changes, J. Appl. Ecol. 30 (1993) 283-294.

[50] Poole D.K., Miller P.C., The distribution of plant water stress and vegetation characteristics in Southern California chaparral, Amer. Midland Naturalist 105 (1981) 32-43.

[51] Rambal S., Water balance and pattern of root water uptake by a Quercus coccifera L. evergreen scrub, Oecologia 62 (1984) 18-25.

[52] Rambal S., Quercus ilex facing water stress: a functional equilibrium hypothesis, Vegetatio 99/100 (1992) 147-153.

[53] Rambal S., The differential role of mechanisms for drought resistance in a Mediterranean evergreen shrub: a simulation approach, Plant Cell Environ. 16 (1993) 35-44.

[54] Rambal S., From daily transpiration to seasonal water balance: an optimal use of water? in: Roy J., Aronson J., di Castri F. (Eds.), Time scale of biological responses to water constraints, SPB Academic Publ., 1995, pp. 37-51.

[55] Rambal S., Debussche G., Water balance of mediterranean ecosystems under a changing climate, in: Moreno J.M., Oechel W.C. (Eds.), Global change and Mediterranean-type ecosystems, 1995, pp. 386-407.

[56] Rambal S., Damesin C., Joffre R., Méthy M., Lo Seen D., Optimization of carbon gain in canopies of Mediterranean evergreen oaks, Ann. Sci. For. 53 (1996) 547-560.

[57] Romane F., Terradas J., Quercus ilex L. ecosystems: function, dynamics and management, Kluwer Academic Publishers, Dordrecht, Netherlands, 1992.

[58] Rosenzweig M.L., Net primary productivity of terrestrial communities: prediction from climatological data, Amer. Naturalist 102 (1968) 67-74.

[59] Roupsard O., Évaluation de la conductance mésophyllienne au $\mathrm{CO}_{2}$ à l'aide de mesures combinées de fluorescence de la chlorophylle et d'échanges gazeux : comparaison d'espèces ligneuses, effets d'une sécheresse et d'un enrichissement en $\mathrm{CO}_{2}$, DEA, Nancy I, 1993.

[60] Running S.W., Microclimate control of forest productivity: analysis by computer simulation of annual photosynthesis/ transpiration balance in different environment, Agr. Forest Meteorol. 32 (1984) 267-288.

[61] Running S.W., Coughlan J.C., A general model of forest ecosystem processes for regional applications. I. Hydrologic balance, canopy gas exchange and primary production processes, Ecol. Model. 42 (1988) 125-154.

[62] Running S.W., Gower S.T., FOREST-BGC, a general model of forest ecosystem processes for regional applications. II. Dynamic carbon allocation and nitrogen budgets, Tree Physiol. 9 (1991) 147-160.

[63] Running S.W., Hunt Jr. R.E., Generalization of a forest ecosystem process model for other biomes BIOME-BGC and an application for global scale models, in: Ehleringer J.R., Field C. (Eds.), Scaling processes between leaf and landscape levels, Academic Press, San Diego, CA, 1993, pp. 141-158.

[64] Sala A., Tenhunen J.D., Simulations of canopy net photosynthesis and transpiration in Quercus ilex L. under the influence of seasonal drought, Agr. Forest Meteorol. 78 (1996) 203-222.

[65] Sala A., Modelling canopy gas exchange during summer drought, in: Rodà F., Retana J., Gracia C.A., Bellot J. (Eds.), Ecology of Mediterranean evergreen oak forests, Ecological Studies 137, Springer-Verlag, Berlin, 1999, pp. 149-161. 
[66] Sampson D.A., Allen H.L., Regional influences of soil available water-holding capacity and climate, and leaf area index on simulated loblolly pine productivity, Forest Ecol. Manage. 124 (1999) 1-12.

[67] Schulze E.D., Kelliher F.M., Korner C., Lloyd J., Leuning R., Relationships among maximum stomatal conductance, ecosystem surface conductance, carbon assimilation rate, and plant nitrogen nutrition: a global ecology scaling exercice, Annu. Rev. Ecol. Syst. 25 (1994) 629-660.

[68] Specht R.L., Specht A., Canopy structure in Eucalyptus-dominated communities in Australia along climatic gradients, Acta Oecol., Oecol. Plant. 10 (1989) 191-213.

[69] Stephenson N.L., Climatic control of vegetation distribution: the role of the water balance, Amer. Naturalist 135 (1990) 649-670.

[70] Stewart G.R., Turnbull M.H., Schmidt S., Erskine P.D., $\delta^{13} \mathrm{C}$ natural abundance in plant communities along a rainfall gradient: a biological integrator of water availability, Aust. J. Plant Physiol. 22 (1995) 51-55.

[71] Teixeira Filho J., Analyse et modélisation du fonctionnement hydrique d'un écosystème forestier. Spatialisation à l'échelle du bassin versant, Ph.D. Thesis, Montpellier II, 1995.

[72] Teixeira Filho J., Damesin C., Rambal S., Joffre R., Retrieving leaf conductances from sap flows in a mixed Mediterranean woodland: a scaling exercise, Ann. Sci. For. 55 (1998) 173-190.

[73] Timbal J., Chorologie des espèces ligneuses françaises. Tome 1. Essences indigènes de la zone méditerranéenne française. INRA,
Centre National de Recherches Forestières, Laboratoire de phytoécologie forestière, Champenoux, France, 1975.

[74] Valentini R., Scarascia Mugnozza G.E., De Angelis P., Bimbi R., An experimental test of the eddy correlation technique over a mediterranean macchia canopy, Plant Cell Environ. 14 (1991) 987-994.

[75] Vertovec M., Sakçali S., Ozturk M., Salleo S., Giacomich P., Feolo E., Nardini A., Diagnosing plant water status as a tool for quantifying water stress on a regional basis in Mediterranean drylands, Ann. For. Sci. 58 (2001) 113-125.

[76] Vivat A., Persistance des feuilles et bilan carboné d'un chêne méditerranéen (Quercus ilex L.) : évolution le long d'un gradient climatique, DEA, Montpellier II, 1995.

[77] Waring R.H., Estimating forest growth and efficiency in relation to canopy leaf area, Adv. Ecol. Res. 13 (1983) 327-354.

[78] Waring R.H., Running S.W., Forest ecosystems, analysis at multiple scales, Academic Press Inc., 1998.

[79] Whittaker R.H., Niering W.A., Vegetation of the Santa Catalina mountains, Arizona. V. Biomass, production, and diversity along the elevation gradient, Ecology 56 (1975) 771-790.

[80] Woodell S.R.J., Mooney H.A., Hill A.J., The behaviour of Larrea divaricata (creosote bush) in response to rainfall in California, $\mathrm{J}$ Ecol. 57 (1969) 37-44.

[81] Woodward F.I., Climate and plant distribution, Cambridge University Press, New York, 1987. 